\title{
Regional Tax Coordination and Foreign Direct Investment*
}

\author{
Andreas Haufler \\ University of Göttingen and CESifo \\ Ian Wooton \\ University of Glasgow and CEPR
2002 Conference of the Royal Economic Society
Warwick, U.K., March 25-27, 2002

\begin{abstract}
The paper analyzes the effects of a regionally coordinated profit tax in a model with three active countries, one of which is not part of the union, and a globally mobile firm. We show that regional tax coordination can lead to two types of welfare gains. First, for investments that would take place in the region in the absence of coordination, this measure can transfer location rents from the firm to the union. Second, by internalizing all of the union's benefits from foreign direct investment, a coordinated policy attracts more investment than when member states act in isolation. Consequently, tax levels may rise or fall under regional coordination.
\end{abstract}

Keywords: tax competition, regional coordination, international investment JEL-Classification: F15, F23, H73, H87

*This paper was started while the second author was at the University of Göttingen and continued while both authors were visiting the Economic Policy Research Unit (EPRU) at the University of Copenhagen. We thank both institutions for their hospitality and seminar participants in Göttingen and Copenhagen, in particular Søren Bo Nielsen and Peter B. Sørensen, for helpful comments. 


\section{Introduction}

It is frequently argued that the increasing international mobility of firms is a main reason for the significant fall in corporate tax rates worldwide. ${ }^{1}$ The more footloose the factor, the more easily it can avoid taxation through migration to a tax haven. Consequently, greater mobility intensifies the competition between jurisdictions in reducing taxes in order to attract corporate investment. In the European Union, these developments have led to an intense debate on whether corporate taxation should be formally coordinated between member states. The Ruding Report (1992) made far-reaching harmonization proposals, including a recommendation for a minimum statutory corporation tax of 30 per cent. These proposals have not, however, been endorsed by EU member states. One of the main counterarguments has been that, as a consequence of the limits on tax competition within the EU, internationally mobile firms might exit the region altogether and settle in third countries.

As an alternative to the Ruding proposals, in 1998 the EU council adopted a Code of Conduct for business taxation in which member states commit themselves to refrain from 'unfair' tax policies that discriminate against (less mobile) domestic firms in favour of (more mobile) multinational firms (see European Communities, 1998). A parallel initiative against discriminatory corporate tax policies has been launched by the OECD (1998). It is by no means clear, however, that this measure will prove sufficient to prevent tax competition for internationally mobile firms. ${ }^{2}$ For example, in response to the Code of Conduct, Ireland will introduce a general corporate income tax rate of 12.5 per cent as of 2003, thus all of its EU competitors by a margin of more than 10 percentage points. ${ }^{3}$ Moreover, with the enlargement of the EU beginning in 2004, a number of Eastern European countries with corporate

\footnotetext{
${ }^{1}$ Statutory corporate tax rates have declined from an OECD average of almost 50 per cent in 1980 to roughly 35 percent in 2000. If effective average rates of corporation tax are considered, and account is thus taken of simultaneous changes in the corporate tax base, the reduction is somewhat less, but is nonetheless substantial. See Devereux, Griffith and Klemm, 2001.

${ }^{2}$ Keen (2002) has recently shown that a non-discrimination policy may even be counterproductive, because it extends the range of tax bases over which countries compete.

${ }^{3}$ In the past, Ireland has given preferential tax treatment to multinational firms by means of a split corporate tax rate.
} 
income tax rates well below the average of the current EU members will enter the internal market. With these changes, it seems almost certain that the debate on a more far-reaching harmonization of corporate tax systems in the EU will be reopened in the coming years.

Against this background, the present paper analyzes the implications of a regionally coordinated, corporate-income tax in a model with three active countries, one of which is outside the region, and a profit-making firm that is freely mobile internationally. The analysis builds on two different strands in the literature.

The first group of papers deals with the issue of tax coordination in such a threecountry model, but focussing on the competition to attract capital. This factor of production earns a normal rate of return. In an influential paper, Razin and Sadka (1991) have shown that tax coordination between two (infinitely) small countries will yield no welfare gains and a zero tax policy is optimal for the coordinating region, if cooperation with the (large) rest of the world is not feasible. However, a coordinated tax increase in a subgroup of countries that is able to influence the world rate of return will be welfare improving. This result holds if tax rates are strategic complements so that countries that are not part of the agreement will find it in their own self-interest to raise domestic tax rates as well (see Konrad and Schjelderup, 1999). Similarly, in the presence of differential transaction costs for investments within the EU and in third countries, Huizinga and Nielsen (2000) show that a tax increase in an EU tax haven will increase welfare in the EU partner country, despite the presence of an outside tax haven. Finally, Sørensen (2000, 2001) carries out a set of simulation analyses in an extended, asymmetric model where countries differ from each other and distributional effects arise within each country. His calculations confirm the qualitative result that a coordinated increase in capital tax rates among the EU members will be beneficial for the union as a whole, but they also show that regional tax coordination promises only a fraction of the gains that could be achieved by worldwide tax coordination.

A second strand of the literature analyzes the effects of tax competition for internationally mobile, profit-making firms when the location of a firm causes spillover effects in the independent, potential-host countries. Examples of positive spillovers are scale economies in the provision of public goods (Black and Hoyt, 1989), the ex- 
istence of regional unemployment (Haaparanta, 1996), or vertical industry linkages that reduce the production costs of existing firms (Haaland and Wooton, 1999). In these settings, a subsidy competition for the firm will result, if the potential host countries have similar characteristics. ${ }^{4}$ When trade costs are incorporated in this type of model, firms will have an incentive to locate either in the larger market (Haufler and Wooton, 1999) or in the country that already hosts an agglomeration (Kind et al., 2000). The host country may then be able to levy a positive tax on mobile firms in equilibrium, even if it benefits from the investment. All these models consider only two competing regions, however, and none explicitly addresses the issue of regional tax coordination. ${ }^{5}$

These two strands are brought together in the present analysis. We consider unilateral and regional tax policy for a region of two countries that competes with a third potential-host country for the location of a monopolistic firm. Location rents arise from transport costs being lower within the region than between the region and the outside country. In this setting, we show that regional tax coordination may lead to two types of welfare gains. First, in situations where the firm's location rent in the region is large, eliminating tax competition within the region allows an increase in the equilibrium tax, leading to a transfer of location rents from the firm to the regional governments. Second, in situations where the firm has no strong preference between locating within the region or in the outside country, a coordinated reduction in the tax offered to the firm will attract additional, welfare-enhancing investments. In this case, regional integration overcomes a free-riding problem when both countries in the region benefit from the investment. Taken together, these results imply that the direction of tax change under regional coordination is ambiguous in our model. This contrasts with the seemingly clear-cut policy prescription in favour of a coordinated tax increase derived in the earlier literature on regional tax coordina-

\footnotetext{
${ }^{4}$ Conversely, non-cooperative capital taxation may lead to excessively high tax rates when the location of a firm causes negative externalities for the host country, for example by polluting its environment (see Markusen et al., 1995).

${ }^{5}$ An informal argument about the potential benefits of regional tax coordination in such a setting is made in Keen (1993, pp. 33-34). Keen argues that only a coordinated tax policy will be able to capture regional location rents that are not specific to a particular country. As our formal analysis will show, this is but one of the possible welfare gains that can arise from regional coordination.
} 
tion, and may explain the hesitation of policy-makers in the EU to enact minimum corporate tax rates or similar harmonization policies.

The analysis proceeds as follows. Section 2 presents the model, describing in turn the behaviour of households, firms, and governments. Section 3 considers the benchmark case where all countries (both countries in the region and the outside country) compete to host the monopolist. Section 4 analyzes the effects of tax coordination between the two countries in the region. Section 5 discusses our results and compares them to related literature. Section 6 concludes.

\section{The model}

We consider tax policy in three countries $i \in\{A, B, C\}$, where countries $\mathrm{A}$ and $\mathrm{B}$ are located in the same region while country $\mathrm{C}$ lies outside the union. ${ }^{6}$ The three countries compete for the location of a single firm that is a monopoly supplier in the world market and has its home base outside the active countries considered in the model. Due to high plant-specific costs, the firm will set up in only one of the countries A, B and C, and serve the other markets from this base. Location matters because of transport costs, which differ between the two countries in the region and the outside country. ${ }^{7}$

\subsection{Households}

There are two consumption goods in each country, the good produced by the monopolist $(x)$, and a numeraire good $(z)$ produced in a perfectly competitive market. Consumers in all countries are identical and have quadratic, quasi-linear preferences of the form

$$
u_{i}=\alpha x_{i}-\frac{1}{2} \beta x_{i}^{2}+z_{i} \quad \forall \quad i \in\{A, B, C\}
$$

\footnotetext{
${ }^{6}$ In the following we refer to countries A and B equivalently as a 'region' or 'union' of countries. The latter term may imply that the two countries may have agreed on some form of policy coordination other than the issue under discussion here, but such pre-existing arrangements have no consequences for our analysis.

${ }^{7}$ This set-up extends our earlier analysis in Haufler and Wooton (1999).
} 
In all countries, each household inelastically supplies one unit of labour, receiving the wage $w_{i}$. Denoting consumer prices by $q_{i}$ and letting $t_{i} / n_{i}$ be per-capita tax revenues, the budget constraint in each country is given by

$$
w_{i}+\frac{t_{i}}{n_{i}}=z_{i}+q_{i} x_{i} \quad \forall \quad i \in\{A, B, C\} .
$$

In the following we assume that countries $\mathrm{A}$ and $\mathrm{B}$ are of equal size and that the population in each of these countries is normalized to unity $\left(n_{A}=n_{B} \equiv 1\right)$. The population of the outside country $\mathrm{C}$ is $n_{C} \equiv n$. Thus our analysis allows for exogenous variations in the relative size of the regional market $(A+B)$ vis-à-vis country $C$.

Maximizing (1) subject to the budget constraint (2) and aggregating over households yields the market demand curve for good $x$ in each country

$$
X_{A}=\frac{\left(\alpha-q_{A}\right)}{\beta}, \quad X_{B}=\frac{\left(\alpha-q_{B}\right)}{\beta}, \quad X_{C}=\frac{n\left(\alpha-q_{C}\right)}{\beta} .
$$

\section{$2.2 \quad$ Firms}

Labour is the only input in the production of both goods. The production function for the numeraire good $(z)$ is the same in all countries and this good is freely traded with no transport costs. This ensures that wage rates will be equalized across countries $\left(w_{i}=w\right)$.

In contrast, commodity $x$ is produced by a monopolist ${ }^{8}$ that has its home base outside of countries A, B and C. ${ }^{9}$ It is well known that the decision whether to export from the home base or engage in foreign direct investment will depend on the comparison between trade costs and fixed set-up costs (Horstman and Markusen, 1992). Since little can be gained from restating these conditions in the present context, we simply assume that firm-specific set-up costs are sufficiently low to make

\footnotetext{
${ }^{8}$ The monopoly assumption is needed to keep the model tractable analytically. In the context of environmental tax competition, Rauscher (1995) introduces the same assumption in the oligopoly model of Markusen et al. (1995). This simplification allows Rauscher to derive analytical results without changing the qualitative implications of the model.

${ }^{9}$ This implies that the monopolist's profits will not enter the calculations of any of the active countries. The case where the monopolist is partly or wholly owned by residents of countries A and B is discussed in Section 5.
} 
foreign direct investment profitable, and plant-specific costs are sufficiently high so that all foreign direct investment is concentrated in a single production unit. Finally, consumer arbitrage for the monopoly good $x$ precludes the firm from pricediscriminating between markets. ${ }^{10}$

In this setting consumer prices will differ across countries by the amount of the transport costs. There is a fixed transport cost of $\tau$ per unit of good $x$ shipped between regions A and B. For trade between either of these countries and country $\mathrm{C}$, the per-unit transport cost is $\sigma$. Transport costs should be interpreted in a wide sense, incorporating all differences between countries that make market integration imperfect. Throughout the analysis we assume $\sigma>\tau$. Different arguments can be given to support this specification. The two markets in the region may be geographically closer to each other than to the third country; there may be fewer administrative hurdles for trade between them; or the two markets in the region may be more similar, so that locating in one reduces the information cost of selling in the other.

The firm's optimal producer price will generally depend on the country in which the investment takes place. Let this location-specific producer price be denoted by $p_{i}$. Adding the relevant level of transport costs gives the following set of consumer prices in country $j\left(q_{j i}\right)$ :

$$
\begin{array}{lll}
q_{A A}=p_{A}, \quad q_{B A}=p_{A}+\tau, \quad q_{C A}=p_{A}+\sigma & \text { FDI in A, } \\
q_{A B}=p_{B}+\tau, \quad q_{B B}=p_{B}, \quad q_{C B}=p_{B}+\sigma & \text { FDI in B, } \\
q_{A C}=p_{C}+\sigma, & q_{B C}=p_{C}+\sigma, \quad q_{C C}=p_{C} & \text { FDI in C. }
\end{array}
$$

The firm's profits from operations in location $i$ depend on the mark-up over wage costs that can be charged, multiplied by worldwide sales under the resulting consumer prices. From these gross profits, fixed plant-specific costs must be deducted. We assume that these are the same across all countries and equal to $F$. Finally, each country levies a lump-sum tax $t_{i}$, which can be positive or negative. The tax instrument thus incorporates both direct investment subsidies paid to the firm and

\footnotetext{
${ }^{10}$ This assumption is motivated by the increasing opportunities for individuals to cross-border shop via the Internet or through other low-cost forms of remote purchases.
} 
(cash flow) taxes on pure profits. ${ }^{11}$

Hence, net profits in location $i$ are

$$
\pi_{i}=\left(p_{i}-w\right) \sum_{j} X_{j}\left(q_{j i}\right)-F-t_{i} \quad \forall \quad i, j \in\{A, B, C\} .
$$

Substituting the market demand curves (3) and the set of consumer prices (4) into (5) and differentiating gives the optimal location-specific prices chosen by the monopolist:

$$
\begin{gathered}
p_{A}^{*}=p_{B}^{*}=\frac{1}{2}\left\{\alpha+w-\frac{(\tau+\sigma n)}{(2+n)}\right\} \quad \text { FDI in A, B }, \\
p_{C}^{*}=\frac{1}{2}\left\{\alpha+w-\frac{2 \sigma}{(2+n)}\right\} \quad \text { FDI in } \mathrm{C} .
\end{gathered}
$$

Equation set (6) clearly shows that the optimal producer price is negatively related to the aggregate transportation costs incurred for worldwide sales from any given production base.

Substituting (6) back into (5) yields optimized profits for each location. Due to symmetry, these are identical in countries A and B. In the following we adopt the convention, with no loss of generality, that the firm always locates in country A whenever it decides to set up production in the region. It is then sufficient to compare profits in countries $\mathrm{A}$ and $\mathrm{C}^{12}$

$$
\begin{aligned}
& \pi_{A}^{*}=\frac{(2+n)}{4 \beta}\left\{\alpha-w-\frac{(\tau+\sigma n)}{(2+n)}\right\}^{2}-F-t_{A}, \\
& \pi_{C}^{*}=\frac{(2+n)}{4 \beta}\left\{\alpha-w-\frac{2 \sigma}{(2+n)}\right\}^{2}-F-t_{C} .
\end{aligned}
$$

Subtracting these two values from each other yields the net profit surplus that can be earned in location A vis-à-vis location C:

$$
\pi_{A}^{*}-\pi_{C}^{*}=\frac{[\sigma(2-n)-\tau] \Theta}{2 \beta}-t_{A}+t_{C}
$$

\footnotetext{
${ }^{11}$ In practice, location subsidies are often granted to the firm by selling land below market price, or by providing public infrastructure for which the firm is not charged. Note also that introducing (more realistic) proportional profit taxes would complicate the algebra, but change none of our results.

${ }^{12}$ Throughout the analysis, we assume that the market size parameter $\alpha$ is sufficiently large, relative to wages, transport costs, and fixed set-up costs, to ensure positive profits for the firm in every location.
} 
where

$$
\Theta \equiv \frac{1}{2}\left[2(\alpha-w)-\sigma-\frac{\tau}{2+n}\right]>0
$$

From eq. (6) we can infer that $\Theta=\left[\left(p_{A}^{*}-w\right)+\left(p_{C}^{*}-w\right)\right]$ is the mark-up of prices over wage costs in both countries. Hence $\Theta$ must always be positive.

The firm will be indifferent between locating in countries $\mathrm{A}$ and $\mathrm{C}$ if $\pi_{A}^{*}-\pi_{C}^{*}=0$. From (8) we can then define $\Gamma$ as the 'tax premium' that the firm is willing to pay for locating in country A vs. country C:

$$
\Gamma \equiv t_{A}-t_{C} \quad \text { where } \quad \Gamma=\frac{[\sigma(2-n)-\tau] \Theta}{2 \beta} .
$$

The sign of this tax premium is ambiguous in general. Country A can charge a higher tax than country $\mathrm{C}$ and still leave the firm indifferent between locations, if the market of the third country is not larger than the regional market $(n<2)$ and transport costs within the region are low relative to transport costs to the third country $(\tau<<\sigma)$.

Figure 1 summarizes the parameter combinations under which the union country A is able or unable to attract the investment in the absence of taxes and subsidies. The figure is drawn for the parameter values $\alpha=2.5, w=1$ and $\sigma=1$ while the market size of country $\mathrm{C}(n)$ and trade costs within the union $(\tau)$ are allowed to vary. The boldface line in the graph gives the combinations of $(n, \tau)$ for which the firm is indifferent between locating in the union and locating in country C. For parameter combinations below this line the firm will settle in the union, whereas it will settle in country $\mathrm{C}$ for combinations above the line. ${ }^{13}$

\subsection{Governments}

Each government compares the welfare of its representative consumer in the scenarios where it is host to the firm to the case where good $x$ has to be imported from abroad. Due to international differences in transport costs, it also matters for each

\footnotetext{
${ }^{13}$ It is directly inferred from Figure 1 that further economic integration in the union (defined as a reduction in $\tau$ ) increases the likelihood of country A attracting the foreign direct investment (cf. Motta and Norman, 1996).
} 


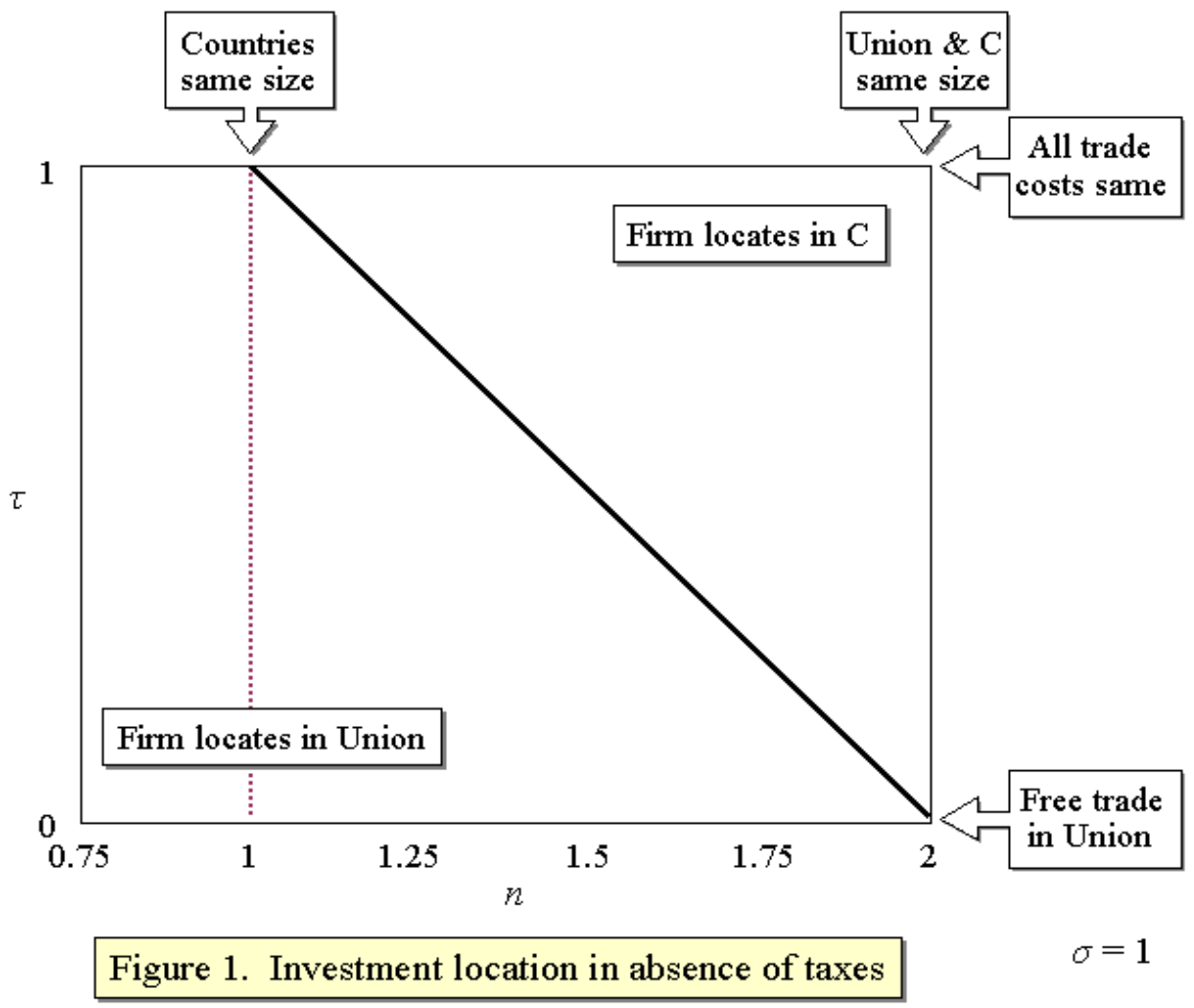

Figure 1: 
of countries A and B whether good $x$ is imported from the neighbouring country in the union or from the outside country C. To compute the welfare levels for country A when the firm locates in country $i\left(u_{A, i}\right)$, we use the budget constraint $(2)$ to substitute out for $z_{i}$ in the utility function (1) and employ (3), (4) and (6). Noting that the tax term $t_{A}$ is zero when country $\mathrm{A}$ is not host to the firm, we get

$$
\begin{gathered}
u_{A A}=\frac{1}{8 \beta}\left\{\alpha-w+\frac{\tau+\sigma n}{(2+n)}\right\}^{2}+w+t_{A}, \\
u_{A B}=\frac{1}{8 \beta}\left\{\alpha-w+\frac{[\sigma n-\tau(2 n+3)]}{(2+n)}\right\}^{2}+w, \\
u_{A C}=\frac{1}{8 \beta}\left\{\alpha-w-\frac{2 \sigma(n+1)}{(2+n)}\right\}^{2}+w .
\end{gathered}
$$

The welfare expressions for country B are analogous, while there are only two different welfare levels for country $\mathrm{C}$, since that country is indifferent as to whether the firm locates in A or B

$$
\begin{gathered}
u_{C C}=\frac{1}{8 \beta}\left\{\alpha-w+\frac{2 \sigma}{(2+n)}\right\}^{2}+w+\frac{t_{c}}{n}, \\
u_{C A}=u_{C B}=\frac{1}{8 \beta}\left\{\alpha-w-\frac{[\sigma(4+n)-\tau]}{(2+n)}\right\}^{2}+w .
\end{gathered}
$$

These equations determine the best offer (i.e., the minimum tax) that each country is willing to make to the firm in order to attract the investment. For country A the tax depends upon whether the firm would otherwise locate in its union partner country B or in the outside country C. In the former case, the minimum tax is obtained by equating $u_{A A}$ and $u_{A B}$ in (11a) and (11b), whereas in the latter case the minimum tax equalizes $u_{A A}$ and $u_{A C}$ [eqs. (11a) and (11c)]. Denoting these minimum taxes by $\mu_{A B}$ and $\mu_{A C}$, respectively, we get

$$
\begin{gathered}
\mu_{A B}=\frac{-\tau}{2 \beta}\left\{(\alpha-w)+\frac{[\sigma n-\tau(n+1)]}{(n+2)}\right\}<0, \\
\mu_{A C}=\frac{-[(3 n+2) \sigma+\tau]}{8 \beta(n+2)}\left\{2(\alpha-w)-\sigma+\frac{\tau}{(n+2)}\right\}<0 .
\end{gathered}
$$


Both of these expressions are unambiguously negative [cf. eq. (9)], indicating country A's willingness to subsidize the firm in order to save transport on costs.

To answer the question as to which alternative location induces a higher subsidy from country A, we calculate

$$
\mu_{A C}-\mu_{A B}=\frac{-[(3 n+2) \sigma-(2 n+3) \tau]}{8 \beta(n+2)}\left\{2(\alpha-w)-\sigma-\frac{(2 n+3) \tau}{(n+2)}\right\} .
$$

Again, it can be shown that the term in the braces in (14) is unambiguously positive. For $n>1$ this implies that $\mu_{A C}-\mu_{A B}<0$, and the minimum tax offered by country A will be lower if the firm otherwise locates in country C. If $n<1$, however, the firm's producer price will be lower when it locates in country $\mathrm{C}$ rather than in one of the union countries. If, in addition, the transport cost differential $(\sigma-\tau)$ is sufficiently small, then $\mu_{A C}-\mu_{A B}>0$ and country A offers a lower tax if the firm would otherwise locate in country B.

For country $\mathrm{C}$, equating $u_{C C}$ and $u_{C A}$ in (12a) and (12b) gives this country's minimum tax

$$
\mu_{C A}=\mu_{C B}=\frac{-n[(6+n) \sigma-\tau]}{8 \beta(2+n)}\left\{2(\alpha-w)-\sigma+\frac{\tau}{(n+2)}\right\}<0,
$$

which is also unambiguously negative.

\section{Tax competition between all countries}

To determine the equilibrium location of the firm, the firm's comparison of net profits [eq. (10)] must be combined with the different minimum taxes offered by the competing countries. We adopt a simple bidding approach where all countries know the location preferences of the firm, as given by (10), and continuously increase their offers (i.e, reduce their profit taxes). In equilibrium, the firm will locate in the country where its net-of-tax profits are (marginally) higher than those in any other location, and neither of the countries failing to get the investment has an incentive to reduce its profit tax further.

We first consider the competition between countries $\mathrm{A}$ and $\mathrm{C}$, ignoring for now the intra-union tax competition between $\mathrm{A}$ and $\mathrm{B}$. We denote by $\kappa$, the critical tax 
that is required to get the investment in country A. This is derived by substituting country C's best offer $\mu_{C A}$ [eq. (15)] into eq. (10). This gives

$$
\kappa \equiv \Gamma+\mu_{C A}=\frac{1}{4 \beta(n+2)}\left\{\left[\left(8-6 n-3 n^{2}\right) \sigma-(4+n) \tau\right] \Theta-\frac{n \tau[(6+n) \sigma-\tau]}{(n+2)}\right\}
$$

where $\Theta>0$ is given in (9). This critical tax will be negative if $n \geq 1$. However, it is positive for sufficiently low levels of both $n$ and $\tau$, in which case the firm has a strong incentive to settle in the union.

In order for country A to attract the firm, the critical tax must exceed the best offer (maximum subsidy) of country A, otherwise the firm will locate in C. Hence the firm will invest in the union if and only if $\kappa-\mu_{A C}>0$. From (16) and (13b) we calculate

$$
\kappa-\mu_{A C}=\frac{\{[(10-3 n(n+1)] \sigma-(3+n) \tau\} \Theta}{4 \beta(n+2)}+\frac{\tau\left[\sigma\left(2-3 n-n^{2}\right)+\tau(n+1)\right]}{4 \beta(n+2)^{2}} .
$$

In Figure 2 this condition is shown graphically by the new line that cuts the horizontal axis at $n \approx 1.38$. To the left of this line, the difference is positive and the firm locates in the union despite intra-union tax competition. In comparison to the scenario without taxes and subsidies (Figure 1), the likelihood of the union attracting the investment is unambiguously lower, as indicated by the shaded area. This is because, for $n>1$, country $\mathrm{C}$ will be willing to offer a higher subsidy than country A, as it has the higher absolute savings in transport costs (Haufler and Wooton, 1999).

In the cases where country A still attracts the investment, the remaining question is which tax level it can charge the firm. If (17) is positive then offering a tax marginally below $\kappa$ will suffice to outbid country C. But, this does not take account of tax competition within the union. Since countries A and B are symmetric, the best offers they can make to the firm are the same. Country A must offer at least the $\operatorname{tax} \mu_{A B}$ in order to prevent the firm from locating in country B. Hence, the equilibrium tax charged by country A when it is host to the firm is

$$
t_{A}^{*}=\min \left\{\mu_{A B}, \kappa\right\} .
$$

Since $\mu_{A B}<0$ from (13a), this minimum condition implies that the equilibrium 


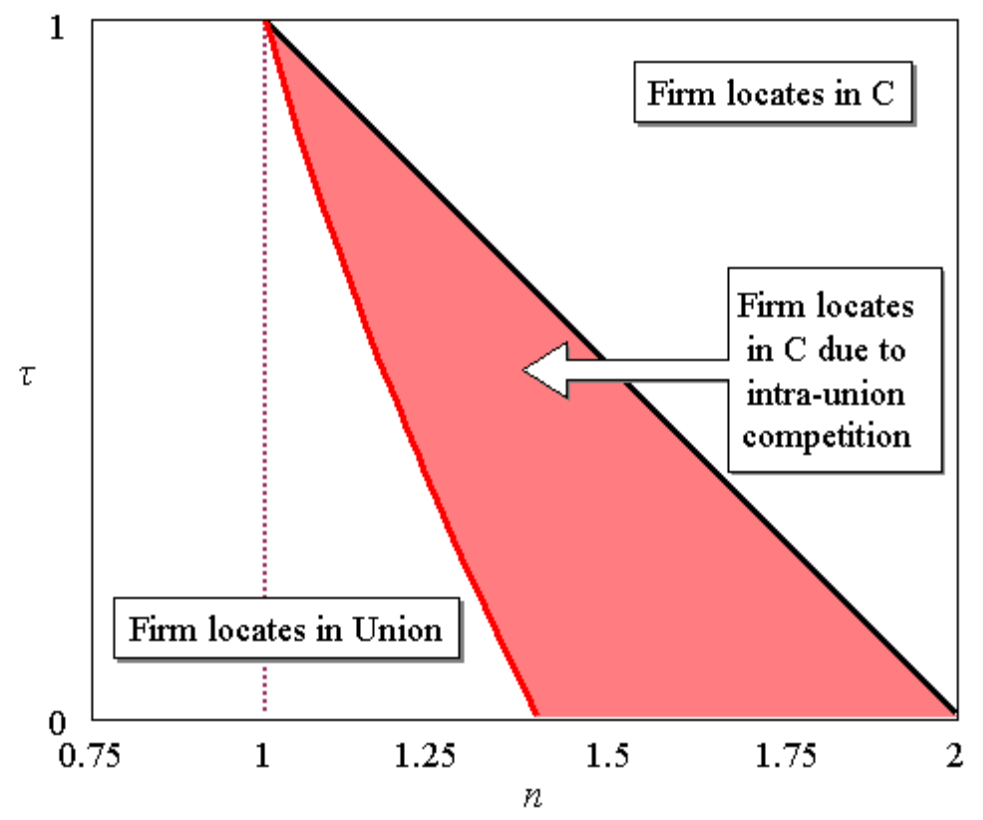

Figure 2. Intra-union and international tax competition

$\sigma=1$

Figure 2: 


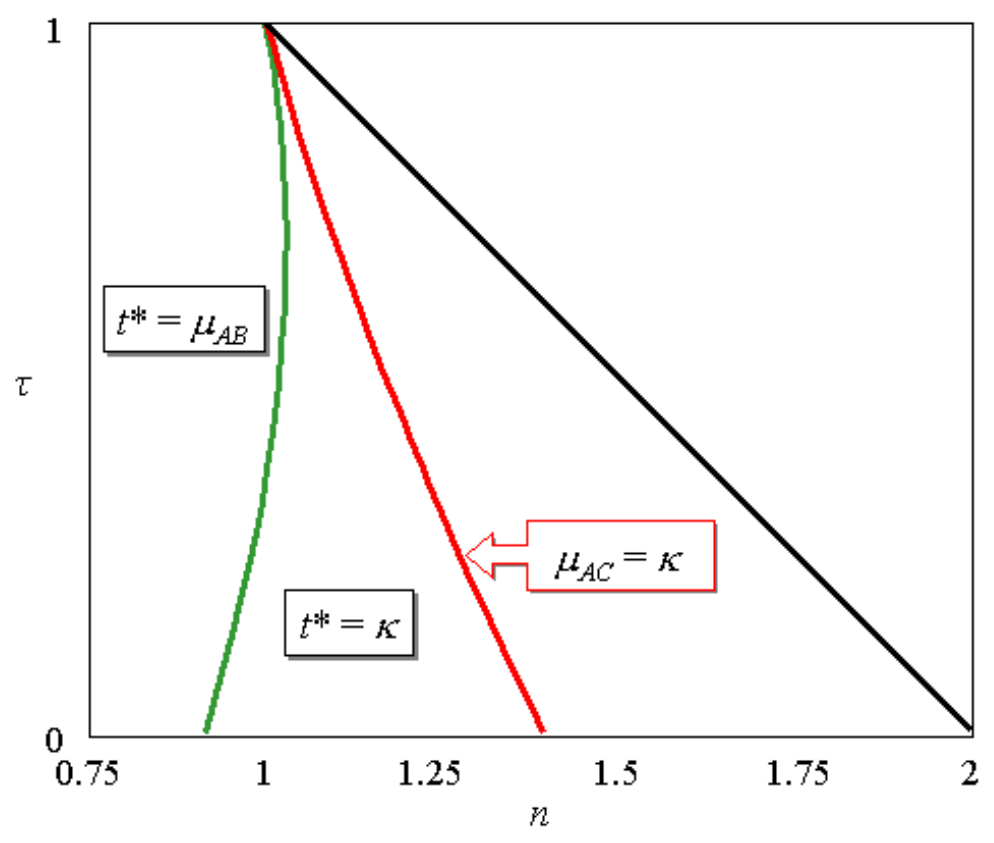

Figure 3. Union tax rates in equilibrium

$\sigma=1$

Figure 3:

tax is always negative for a union country that successfully attracts the firm in the presence of intra-union tax competition.

Figure 3 shows which of the two tax levels is binding for different sets of parameter values. In this graph only parameter combinations to the left of the $\mu_{A C}=\kappa$ line are relevant, since country A will not attract the investment in the remaining cases. If, starting from any point on the $\mu_{A C}=\kappa$ line, the size of country $\mathrm{C}$ is gradually reduced while $\tau$ is held constant, the regime where country C's tax offer imposes the binding constraint will be reached first, implying $t_{A}^{*}=\kappa$. If $n$ is further reduced, intra-union tax competition becomes the binding constraint and $t_{A}^{*}=\mu_{A B}$. 


\section{Regional tax coordination}

We now consider the case where the union countries $A$ and $B$ coordinate their policies and jointly make a tax offer to the firm. This offer will take into account the combined benefits to both countries of the firm locating in the region rather than in country $\mathrm{C}$. We maintain our convention that, if the firm invests in the union, it settles in country A.

The maximum offer made under this coordinated policy is thus the sum of $\mu_{A C}$ in (13b) plus the benefit to country B of the firm locating in A rather than C. From the symmetry of the two union countries, this latter benefit is equal to $\mu_{A C}-\mu_{A B}$, as calculated in (14). The combined minimum tax for the union is thus $\mu_{U}=2 \mu_{A C}-$ $\mu_{A B}$, which equals

$$
\mu_{U}=\frac{-1}{4 \beta(n+2)}\left\{2[(3 n+2) \sigma-(n+1) \tau] \Theta+\frac{\tau\left[\left(2 n^{2}+5 n+4\right) \tau-n(3 n+2) \sigma\right]}{(n+2)}\right\} .
$$

This minimum tax will be lower than the best offer of country A if and only if country B benefits from having the firm locate in A rather than C. From our discussion of eq. (14) above, we know that this condition must always be fulfilled for $n \geq 1$.

Given this offer, the equilibrium condition for the firm to locate in the union is $\kappa-\mu_{U}>0$. Computing this difference from (16) and (18) yields

$$
\kappa-\mu_{U}=\frac{1}{4 \beta}\left\{3[(2-n) \sigma-\tau] \Theta+\frac{2 \tau[(n+1) \tau-2 n \sigma]}{(n+2)}\right\} .
$$

Figure 4 summarizes the parameter combinations for which this expression is positive. The union country will attract the firm for all values of $(n, \tau)$ to the left of the line that cuts the horizontal axis at $n=2$. For $\tau=0$ this is the same critical size of country $\mathrm{C}$ as in the case without taxes and subsidies (see Figure 1).

The first important difference to the case of intra-union tax competition (Figure 2) is that the coordinated tax policy will never make a better offer than is needed to prevent the firm from locating in country C. In other words, the equilibrium tax in the coordinated case is always

$$
t_{A}^{*}=\kappa
$$




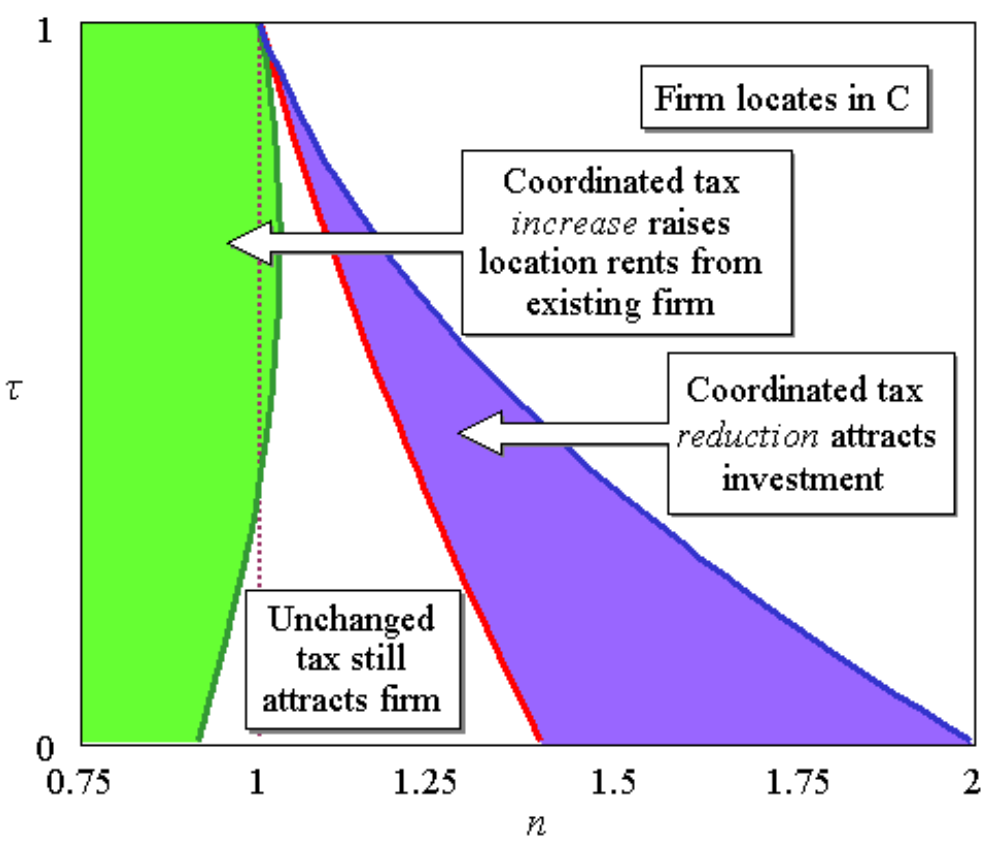

Figure 4. Regional tax coordination

$\sigma=1$

Figure 4: 
Therefore, in situations where the firm has a strong preference to locate in the region and intra-union tax competition imposed the binding constraint on country A's tax offer, a coordinated tax policy will lead to a higher tax in equilibrium, and thus transfer some location rents from the firm to the treasuries of the union countries. This is the lightly shaded area in Figure 4, which corresponds to the regime $t^{*}=\mu_{A B}$ in Figure 3. If the outside country is sufficiently small, then $\kappa$ may actually be positive [cf. eq. (16)] and the union will be able to charge a positive tax from the firm. This cannot occur with intra-union tax competition where, as we saw above, the equilibrium tax will always be negative.

Second, in comparison to the case of intra-union tax competition the union recaptures the investment for the set of parameter combinations indicated by the darkly shaded area. In all of these cases, country B benefits from having the investment in $\mathrm{A}$, rather than in $\mathrm{C}$, and hence the coordinated tax offer $\mu_{U}$ is lower than country A's isolated tax offer $\mu_{A C}$. Welfare gains to the union can thus be obtained by offering a lower tax to the firm, as compared to the case where individual member states submit separate bids. In this scenario the additional location rent to the union, relative to the case of intra-union tax competition, lies in the difference between the equilibrium tax that must be offered to the firm $\left(t_{A}^{*}=\kappa\right)$, and the minimum coordinated tax that the union is willing to offer $\left(\mu_{U}\right)$.

Lying between these two cases where regional tax coordination is welfare increasing (but with opposite implications for the direction of the coordinated tax reform), there is a set of parameter combinations where tax coordination has no effect. This is the white area in between the two shaded ones in Figure 4, which corresponds to the regime $t^{*}=\kappa$ in Figure 3. Here the union will be able to attract the firm even if all countries compete against each other, and the binding constraint on the host country's tax level stems from the tax offer made by the outside country.

\section{Discussion}

We first compare our results with those of earlier work on regional tax coordination in a three-country setting (Konrad and Schjelderup, 1999; Huizinga and Nielsen, 2000; Sørensen, 2000, 2001). A common result of these analyses and ours is that tax 
coordination is collectively beneficial for the region that undertakes the agreement. However, in the previous literature welfare-improving tax coordination always leads to an increase in the rates of capital taxation, which reduces the deadweight loss of the tax system. In our model this is only one of two possible scenarios, and tax coordination may also involve a reduction in the tax offered to a monopolistic firm. This latter policy may yield welfare gains because all of the benefits from attracting foreign direct investment to a region are internalized under tax coordination, including those of countries that do not host the firm. Such spillovers on neighbouring countries in the region are not captured by standard settings of capital tax competition, but arise in our model from differences in transport costs for trade within the region and between the region and the outside world.

Relatedly, the previous literature typically finds that the countries outside the union also benefit from the regional increase in tax rates (see Konrad and Schjelderup, 1999; Sørensen, 2000, 2001). As a consequence, models of tax competition in competitive capital markets predict that regions should share a common interest in collectively raising capital tax rates, at least if they are sufficiently similar in size and other characteristics. This scenario raises the question why we do not observe more intensive efforts at worldwide tax coordination. In contrast, our setting introduces potentially conflicting interests between the union and the outside country. In particular, a coordinated tax reduction in the union will harm the outside country by redirecting foreign direct investment towards the integrating region. Moreover, this scenario becomes more likely when regions are similar in their suitability as locations from the perspective of the firm, as the change in tax policy is then more likely to tip the balance of the firm's investment decision.

In the present model, savings in transport costs are the underlying motive for governments trying to attract internationally mobile firm, and for the positive spillovers that exist for other countries in the region. This motive could be replaced by technological linkages that exist between the production of the monopolistic firm and the producers of other goods in the host country of the investment (see Haaland and Wooton, 1999; Kind et al., 2000; Baldwin and Krugman, 2000). It could further be argued that neighbouring countries will also experience some positive technological spillover from the location of the firm. Such a setting should yield similar qualita- 
tive results for the effects of regional tax coordination as does our specification with transport costs. Hence, the basic argument derived from our analysis is not confined to the case where all firms produce final consumer goods, but it can equally be applied to tax competition for a firm producing specialized intermediate inputs.

We now discuss the likely effects on our results of relaxing some of the underlying assumptions of our model. We have excluded the profits of the firm by assuming that they accrue to the residents of a (fourth) country not explicitly considered in the analysis. The firm's profits are clearly affected by both forms of tax coordination. They are reduced if the firm has a strong incentive to settle in the region, and the union countries collectively increase taxes to extract more location rents from the firm. In contrast, the firm's profits increase if the union countries collectively reduce taxes in order to bid the firm away from country C. If the firm is partly owned by residents of the union, then the union countries' changes in tax revenue are partly offset by counteracting changes in private profit income. This extension will reduce the gains from a coordinated tax increase in the union, but it will increase the gains from a coordinated tax reduction since the additional subsidies now partly accrue to domestic residents.

The benefits of regional tax coordination will also be affected if lump-sum taxes and subsidies are ruled out and distortionary taxes are the governments' marginal source of finance. Other things equal, this will put a premium on taxes raised from the firm and therefore increase the gains from a coordinated tax increase. The reverse is also true as this modification imposes an extra cost on subsidies paid out to the firm, and hence reduces the gains from a coordinated tax reduction. Note, however, that these departures from our results work in the opposite direction to the introduction of profit income accruing to residents of the union. Therefore, on the basis of these two simplifications alone, a setting where lump-sum taxes exist and all profit income accrues to non-residents may be seen as a simple benchmark that does not systematically bias the results in any particular direction. 


\section{Conclusions}

In this paper we have argued that regional tax coordination in a setting with a monopolistic firm and an outside country can lead to two types of welfare gains for the countries undertaking the agreement. First, for investments that would have taken place in the union in the absence of coordination, coordination allows an increase in equilibrium taxes, transferring location rents from the firm to the union countries. Second, by internalizing the benefits to all union members from the location of a foreign production plant, the union as a whole may be able to attract the firm by means of a lower tax (or higher subsidy), whereas non-cooperative tax policies of its members would have caused the firm to settle outside the region.

These results seem to strengthen the policy case for a regional coordination of corporation taxes. But the analysis has also shown that the direction that a regionally coordinated tax reform should take is far from clear. Most of the policy discussion in the EU, along with the results from previous research, suggest a coordinated increase in corporation taxes. Yet the opposite conclusion is equally possible in a world where countries outside the region are not part of the agreement. Hence, the optimal coordinated policy for an integrated region such as the EU involves trading off changes in the location rents that can be reaped from existing firms with those associated with an increase or reduction in the number of firms that locate within the region.

The trade-off just described holds for a scenario where only a single tax instrument (the corporate income tax) is available to the union. In order to simultaneously increase the location rents from existing firms and attract new firms to the region, a richer set of tax instruments is needed. For example, a coordinated EU corporate tax policy could consist of a firm-specific location subsidy, which ensures that foreign direct investment with a positive net value to the union is indeed attracted, and a coordinated tax on corporate profits that avoids a mutual undercutting of individual EU member states. In this case a coordinated EU tax policy would, however, use similar discriminatory policies as have just been declared as 'unfair' at the level of individual member states, and it is bound to create conflicts with the worldwide non-discrimination standards set by the OECD. 
Finally, our analysis also holds some implications for the precise form that regional tax coordination should take. Throughout, we have considered only the welfare effects that regional tax coordination has on the union as a whole, leaving aside the issue of how these gains can be divided between individual member states. In particular, in situations where coordinated tax policy results in a lower tax than the maximum bids of each individual country, the host country would need to receive side-payments from its union partners in order to submit a bid that is sufficiently low to attract the firm to the region. The most straightforward way to overcome this coordination problem would be by means of a centralized EU corporation tax. On the other hand, the analysis has also shown that permitting bids by individual countries is a means of internalizing the positive spillovers that each country perceives from the location of mobile firms. A centralized EU corporation tax would eliminate this preference-revelation mechanism. Hence while this instrument could lead to an efficient distribution of firms between the EU and the rest of the world, it does not simultaneously guarantee an efficient distribution of firms between individual EU member states. 


\section{References}

Baldwin, R. and P. Krugman, 2000, Agglomeration, integration, and tax harmonization. CEPR Discussion Paper No. 2630. Centre for Economic Policy Research, London.

Black, D.A. and W.E. Hoyt, 1989, Bidding for firms. American Economic Review 79, 1249-1256.

Devereux, M.P., R. Griffith and A. Klemm, 2001, Have taxes on mobile capital declined? Paper presented at the conference World Tax Competition, London, U.K., May 24-25, 2001.

European Communities, 1998, Conclusions of the ECOFIN Council meeting on 1 December 1997 concerning taxation policy (including code of conduct for business taxation). Official Journal of the European Communities 98/C 2/01. Brussels.

Haaland, J. and I. Wooton, 1999, International competition for multinational investment. Scandinavian Journal of Economics 101, 631-649.

Haaparanta, P., 1996, Competition for foreign direct investment. Journal of Public Economics 63, 141-153.

Haufler, A. and I. Wooton, 1999, Country size and tax competition for foreign direct investment. Journal of Public Economics 71, 121-139.

Horstman, I.J. and J.R. Markusen, 1992, Endogenous market structures in international trade (natura facit saltum). Journal of International Economics 32, 109-129.

Huizinga, H. and S.B. Nielsen, 2000, The taxation of interest in Europe: A minimum withholding tax? In: S. Cnossen (ed.), Taxing capital income in the European Union, 135-160. Oxford University Press.

Keen, M., 1993, The welfare economics of tax co-ordination in the European Community: A survey. Fiscal Studies 14, 15-36. 
Keen, M., 2002, Preferential regimes can make tax competition less harmful. $N a$ tional Tax Journal, forthcoming.

Kind, H.J., K.H. Midelfart Knarvik and G. Schjelderup, 2000, Competing for capital in a "lumpy" world. Journal of Public Economics 78, 253-274.

Konrad. K. and G. Schjelderup, 1999, Fortress building in global tax competition. Journal of Urban Economics 46, 156-167.

Markusen, J.R., E.R. Morey and N.D. Olewiler, 1995, Competition in regional environmental policies when plant locations are endogenous. Journal of Public Economics 56, 55-77.

Motta, M. and G. Norman, 1996, Does economic integration cause foreign direct investment? International Economic Review 3\%, 757-783.

OECD, 1998, Harmful tax competition: An emerging global issue. Paris.

Razin, A. and E. Sadka, 1991, International tax competition and gains from tax harmonization. Economics Letters 3\%, 69-76.

Rauscher, M., 1995, Environmental regulation and the location of polluting industries. International Tax and Public Finance 2, 229-244.

Ruding Report, 1992, Report of the committee of independent experts on company taxation. Brussels and Luxembourg.

Sørensen, P.B., 2000, The case for international tax coordination reconsidered. Economic Policy 31, 429-472.

Sørensen, P.B., 2001, International tax coordination: Regionalism versus globalism. CESifo Working Paper 483. University of Munich. 